\title{
Energy Unavailable for Useful Work in a System Undergoing Change $\cdot$ Kathleen Fraser
}

\author{
from Leda. \& Swan., a work-in-progress
}

SHE PUSHES a silver pin into the fourth corner of the ink-on-paper drawing. The fourth corner has been unanchored for days.

She has noticed it again, as she sits down and becomes calm, in focus. She has noticed the loose corner of the drawing before and has instructed herself to go get another pin.

Pin it down.

But as soon as she leaves this room, there is the back porch with its large old windows to look out of towards the valley, the bridge, Mt. Diablo's pale Oriental cone on a clear day. Or she opens the door into the kitchen where, noticing the bowl of fruit, she forgets the loose corner.

She savors the sugar-mottled surface of the tangerine, its bright rind nuzzling against the navel orange, paler and thin-skinned but true to its umbilical folds. Its entrance to the body's thousand liquid parachutes.

The bananas have disappeared. There were four. David ate two in a row, breaking them from the bunch the instant after she had arranged their curving tubular forms at an angle to the brown Bosc pear. Winter Nellis pears. Anjou.

Once, she brought four kinds of plums to her friend's house as a contribution to the dinner. She found a small space in the conversation in which to say: Damson, Greengage, Sugarplums, Kelsey.

I dropped the words into the air, heavy and dark. I arranged the names so that her friends could taste the suggestion of more than those round green and purple fruits. She wanted that particular season on their tongues, a certain history of soil and gardeners carrying roots wrapped in cotton handkerchiefs from Genoa and Malaga. (I am inventing this part; what I wanted, then, was a kind of instant pleasure of distinctions tasted only in language.) 
This is a demonstration of how I lose sight of the fourth corner, which I had initially pinned in place when displaying Karl's dense and troubled drawing in the bathroom, above the light switch and next to the Creeley poem:

$$
\begin{aligned}
& \text { There is a world } \\
& \text { underneath, or } \\
& \text { on top of } \\
& \text { this one-and } \\
& \text { it's here now. }
\end{aligned}
$$

It was the first poem David ever responded to with excitement. I won't forget how he came out of the bathroom one afternoon, when he was nine. His eyes were shining when he told me. Someone had said it. This thing he knew and had been carrying alone, inside himself, at night, in his room.

When she notices the fourth pin missing and the feeling, again, of something unfinished, she also catches a faint odor of expensive cigar smoke lingering. It belongs to Karl who has arrived earlier, with long-stemmed Japanese iris, he whom she can now name, who has the attractive quality of attending to loose corners at the time he notices them. She is more than often preoccupied with the interior, so she borrows his eyes in this peculiar way. She thinks of how he would pin down this loose corner, soon after seeing it. Then she goes to find a pin, unless there is something out the window which distracts her-tonight's almost full moon with its unusually deep, bisque-bright aureole.

She is unfinished. She is structurally out-of-breath. When she comes close to something achieved, she enters a low and constant warning buzz. On Sunday, in the middle of her exercises, she begins to cry quite unexpectedly. The fourth corner loose, unanchored, unattended. She can't seem to stop. 
The dream begins this way:

$\mathrm{He}$ is sitting with this younger, dark-haired, smart-mouthed woman who, when I come up to them, is utterly indifferent to me and will not acknowledge me with any eye-contact. David and I have been in the concert hall where Karl has brought us, listening faithfully to a complicated and somewhat chaotic concert of "new music." The concert takes place in a large tent, filled with people. Karl has grown restless and has disappeared. When the performance is over, we go to look for him and find him laughing and talking with the other woman. They are sitting on metal fold-up chairs, completely apart from any of the other people in the audience. It is cold. I notice that he has done exactly what he wants, while I have remained where he brought me. I slide up to him playfully, as if to third base after making a hit. "You are sitting with someone beautiful," I say in a playful mood of acknowledgement. He is neutral. She avoids me.

Dark purple iris, long green curving leaves and stem. Tangerine.

Then, a cruelty. He is calling her on the phone, with me standing right there. He is being his most charming, flirtatious self. He is saying, "I was really knocked-out, just now, by everything you've been telling me. How about letting me knock you out with $m y$ irristible version of life."

This text is using the pronoun "I." This text often makes the "I" central. ("Too personal," "too self-referential" . . the pig critic grunts and roots.)

She wakes up in historic time. Low-grade hysteria. Abandoned feelings from the dream, as real as if this had really been happening just now"There is a world / underneath, or / on top of". . . she likes the way the comma makes a pause before the lurch of $o r$.

And it's here now. 
She lies awake but feels unable to move. The passion of their early morning love has been washed from her by the dream's refusal to leave. Its teeth still graze her neck. He comes back into bed. He holds her. With intention. He holds her head, her face. He kisses her face. He looks. He gazes her to him. She tries to re-learn his face with her numb fingers. She tries to leave the blindness. He kisses her face again and again with a pause after each tenderness. She hears his love coming in, though he doesn't say a word.

I am mute and he covers me with his gaze. He pulls me into belief. He pours me into myself. I remember. I begin to remember what it is like, who he is for me now. He is not the person in the dream. Yet he is, in some way that grazes my dream, in which I split myself into two selves who do not know if it is safe to acknowledge each other's existence. Difficult music. Seeing it through to the end. These two women threaten each other. He likes them both.

After months of starting and stopping, not liking what I write, not finishing, I have, meanwhile, been building the difficult structure of belief, of trust.

Entropy: energy unavailable for useful work in a system undergoing change.

A thought arrives to derail her. Water the plants. A distraction to inhibit this dread, this struggle to claim oneself by inventing it out of thin air, in each push against gravity. The pull of the given. Abandoning herself forever, to it. Turning her back. Shutting the door on the known. 
He has given her a new pen. The point is fine. It makes a line that gives her pleasure. It invites her writing, she thinks, as if in some way there were a bird harnessed to it. Taking off. A swan, she thinks. She has harbored in her mind a duckling who honks awkwardly and swims in circles, who forgets the long stretch of the imagined neck, the rising into air, leaving the earth's insistence. The pull down pulls. It doesn't want her feathery ascension. Oh Mother, oh Father, do not do me in.

The unwillingness to take one's own most. To work for it. To work is to push against the mud, to push against inertia. Fear of not staying aloft. Falling. Falling. Fear of maintaining altitude, of not maintaining altitude. The will, to go up.

Catching the up-draft - the way gulls do, out at the beach, a pure attention to air currents as they glide by at a tilt.

Inertia, ennui, losing momentum, lights dimming, broken generator. Letting someone erase you. Not wanting you there. Saying the sky is private property. Ours.

Ours $=$ not yours.

But generating for another? One good way to accelerate the imagination. Because another takes notice, has an eye which delights in the insect's shining carapace. Worries about a spot of spilled chocolate. Pulls the table's unsteady supports into place. Facing him, has she lost her place?

He finds it. A divining rod at the whiff of water, just underground.

“I don't know why I'm crying. I can't seem to stop. There's nothing wrong I can think of."

"Maybe it's because you're so happy."

"Isn't that ridiculous?" 
She has put her trust in him. Put her trust.

She reads Fannie Farmer with a certain vividness:

About Plums: Height of Season: July and August. What to look for. Plump fruit with good color, slightly soft but with smooth, unshriveled skins - purple, red, blue, yellow, green - and may be round or oval in shape. About Persimmons: Availability: October through December. What to look for. Deep orange or red color with green cap intact and no signs of damage.

Saying those sentences aloud gives pleasure. She locates something found in the world's structure.

Back at her place, she notices a tear in the lining of the lamp. She wonders if it has always been there. She notices a large piece of cracked paint peeling back from the perfect Desert White of the ceiling. The light fixtures are naked, dusty Sylvania bulbs bulging asymmetrically for years from their sockets. Exposed. One could spend a life fixing, arranging, mending, covering, improving, touching-up. She'd rather touch. Yet there did remain this yearning for completion, symmetry, a formal ascendancy to the next level. Her attempts were full of falterings and lurchings They were insufficient, awkward, premature, repetitive. They were loose threads, a button missing. A pin falls. The drawing is unanchored.

Trying to become perfect, a way of pulling against this displacement.

She has chosen this distinction to hover over, to use as a certain axis for mobility. Wing flutter. Warming up. Finding her wingspan. Wanting the other's witness. See me! This insatiable woman, this hooded young girl. She needs this, oh she needs. And not just anyone's.

Not to lean. Do not lean. Not to ask for a little prize. A little Hershey's kiss, with a message for you tucked inside the foil wrap. She is breaking the code. She is a system undergoing change. 
There are mirrors. They are mirrors. She is not enough, alone, in that silvery image returning herself to itself. She wants to push off, to transcend what she knows. The lover's invitation is her sinew. So, now:

A little essay in the middle, or a little more traveling circuitously to locate a thought's progress, as she's begun to track it down.

When, for years, she had to push hard against adversity, when outside the tent she had to stand in the presence of his life with others' crossed legs, dark hair, folding metal, face turned away, then she knew herself daily in each wish and motion. Adrenalin packed itself into every cell and sent her information. On the alert, productive, she learned not to gag on the truth, which gave her substance. And form. She felt new strength in each bit of flesh grown wily with feathers. Her power was in eiderdown. her power was in a sudden rush from the mud, into bright air hovering. A shaking-out of golden light. A phoenix in her with a different sort of song. A reclassification of duck into swan. Sunday into Monday. Dross into slippers that fit. Her desire was on a grand scale and she empowered it as vision. Slowly, belief. Then a seizure of voice. Asking for, saying this. This is what I want. And it's here, now.

Now, he one day wanted. Now, she did have. Now he had suggested a life. She'd heard it dimly at first through the glass pane she'd nailed across her brow. Now had stretched into a year. It was here. Is near. And holds her inside his belief in her, holds tightly and won't let go. She knows this. She says: It is so. It is. So.

To lift off, to remain in her strength in the air. Gets circling but gets lost but loves this Sunday papers/French Roast; this Fred Astaire/Art Tatum lemon-in-the-dressing; this fifth-floor, high-windowed view of waving flags above rooftops of grand hotels; this tasting of the white wine and the red; this making the bed from both sides, loving in the middle on both sides, this burnished black and burnt orange. Pomegranate. Tangerine. 
We talk of what we think and what we see. With him I see more. I sniff and I listen. Then I tell him what I understand. My sentences begin to gain confidence. I am storing up belief. It has been a lifetime, waiting for now. There is a world / underneath, or / on top of / this one-and / it's here. How to be in it? Absolutely. Without penury of soul. To give but not to lose, that self who risked everything and felt the swan's neck stretching in her own.

She had been writing a poem in her dream. It was exactly the one she'd been waiting for. It showed her how her writing wanted to go. She was saying the lines over and over so as not to forget them on waking. But she could only hold onto the last line which said: "All I wanted was to feed the white swans."

The dream:

All I wanted was to feed the white swans. They did not glide on water but traveled in packs on flat dirt beneath trees which were green, large of leaf and effulgent. We were walking near them. The white pebbles were their food and lay glistening on raised wooden trays. Rick beckoned to me and approached the swans; he understood their food, how it should be scattered, and his clothes were soft and dark from living in the woods. His hand beckoned, he was my guide, there was a gravity in his walk, a separateness. The swans moved in large formations which shifted. Their wings did not shine but were slightly dusty. They grouped and scattered, grouped and scattered, keeping a gliding pattern. I wanted to feed them their white food. I wasn't afraid. I was moving towards the shining pebbles and I was concentrated in my task.

"What do you make of the white stones?" I asked my friend Daidie. She said that white stones were magic objects, to be held in high regard. She said in many ancient stories this sort of pebble was an object of power, 
the sustaining food of the soul. "Manna from heaven," Karl had suggested. I remembered, then, the dish of shiny white buttons in another dream, earlier in the summer. I remembered my blindness in this dream, how I had tried to explain to someone from a past life that I'd changed, that I was no longer the person he'd known. "I am not who you think I am. There is nothing to eat but a dish of white buttons."

Now the swan food arrives on its wooden trays. The words unloose in me. The earth is tipping into dawn after twelve hours of darkness. I want to be in the company of swans, catching my own currents. My dream has provided the peculiar glistening food. My mouth waters. Something outside is pulling. 